\title{
Streptococcus pneumoniae Serotype 19A IgG Antibody Measurement
}

National Cancer Institute

\section{Source}

National Cancer Institute. Streptococcus pneumoniae Serotype 19 A Ig G Antibody

Measurement. NCI Thesaurus. Code C142267.

The determination of the amount of Streptococcus pneumoniae serotype 19A Ig G antibody present in a sample. 